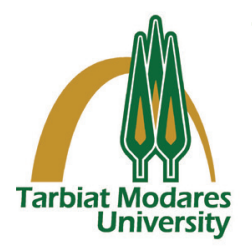

\title{
Simultaneous Detection of Bovine Rotavirus (BRV) and Bovine Viral Diarrhea (BVD) virus in Diarrheic Stool Samples: A Comparative Study of Molecular and Serological approaches
}

\section{A R T I C L E I N F O}

\section{Article Type}

Original Research

\section{Authors}

Mohammad Mehdi Ranjbar, $P h D^{1^{*}}$ Soodeh Enayati, $M S c^{2}$

Mohsen Lotfi, $P h D^{1}$

Ali Reza Yousefi, $P h D^{1}$

Seyed Mahmoud Azimi, $P h D^{1}$

Seyed Reza Mousavi, $P h D$

Sajjad Yazdansetad, $P h D^{3}$

Gholamreza Karimi, $P h D^{1}$

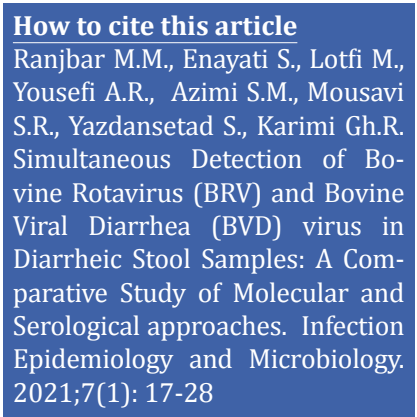

${ }^{1}$ Foot and Mouth Disease Reference Laboratory, Razi Vaccine and Serum Research Institute, Agricultural Research, Education, and Extension Organization (AREEO), Karaj, IR Iran ${ }^{2}$ Department of Biotechnology Research and Science Branch, Islamic Azad University, Tehran, IR Iran ${ }^{3}$ Laboratory Sciences Research Center, Golestan University of Medical Sciences, Gorgan, IR Iran

\section{* Correspondence \\ Address: Foot and Mouth Disease Ref- erence Laboratory, Razi Vaccine and Serum Research Institute, Agricultural Research, Education, and Extension Organization (AREEO), Beheshti Ave., Hesarak, Karaj, Alborz Province, Iran. Tel: +989163033597 mm.ranjbar.phd@gmail.com}

\section{Article History}

Received: October 05,2020

Accepted: November 15,2020

Published: January 23,2021

\section{A B S T R A C T}

Background: Calf scours (diarrhea) in unweaned calves play a major role in economic losses of animal farming industry worldwide. The present study was conducted to investigate and interpret the presence of BRV, BVDV, and Escherichia coli K99 by molecular and serological approaches simultaneously.

Materials \& Methods: A total of 73 E. coli-negative diarrheic fecal samples were collected from one-week to less than one-month-old calves of Holstein dairy cattle herds of some provinces of Iran during autumn and winter. The samples were directed to antigen detection by ELISA (Enzyme Linked ImmunoSorbent Assay), RNA extraction by semi-manual approach, and cDNA synthesis for PCR amplification.

Findings: Out of 73 calves' diarrheic fecal samples, 28 (38.3\%) and $1(1.36 \%)$ were positive for BRV and BVDR by ELISA, respectively. However, 31 (42.4\%) samples were positive for BRV and non for BVDV by RT-PCR. The Kappa coefficient showed significant differences in BRV and BVDR detection between ELISA and RT-PCR methods. The distribution of the BRV-positive samples among bovine diarrheic calves was 80, 52.6, and 50\% in Eslamshahr, Qazvin, and Hamedan, respectively.

Conclusion: ELISA and RT-PCR indicated high prevalence rate of BRV in autumn and winter, respectively. The present study results showed that positive cases detected by RT-PCR were more than those detected by ELISA. Further studies are needed to achieve a comprehensive preventive and therapeutic strategy to address diarrhea bovine pathogens.

\section{Keywords: Bovine rotavirus, Bovine viral diarrhea virus, Calf, ELISA, RT-PCR.}

\section{CITATION LINKS}

[1] Achá SJ, Kühn I, Jonsson P, Katouli ... [2] Hur T-Y, Jung Y-H, Choe C-Y, Cho YI, Kang SJ, Lee HJ, et al. The dairy ... [3] Østerås O, Gjestvang MS, Vatn S, Sølverød ... [4] Reynolds DJ, Morgan JH, Chanter N, Jones PW, Bridger JC, Debney TG, et al. ... [5] Bartels CJM, Holzhauer M, Jorritsma R, ... [6] Izzo MM, Kirkland PD, Mohler VL, ... [7] Cho Y, Yoon K-J. An overview of ... [8] Chen S-C, Tan L-B, Huang L-M, Chen ... [9] Greenberg HB, Estes ... [10] Iturriza Gómara M, Wong C, Blome S, ... [11] Maclachlan NJ, Dubovi EJ. Retroviridae: Fenner's ... [12] Dhama K, Chauhan RS, Mahendran M, Malik SVS. Rotavirus diarrhea in ... [13] Martella V, Bányai K, Matthijnssens J, ... [14] Buesa J, Colomina J, Raga J, Villanueva A, Prat J.... [15] Fan Q Xie Z, Xie Z, Deng X, Xie L, Huang L, et al. Development of ... [16] Garoussi MT, Mehrzad J, Nejati A. Investigation of ... [17] Liu L, Xia H, Wahlberg N, Belák S, Baule C. Phylogeny, classification ... [18] Grøndahl C, Uttenthal A, Houe H, ... [19] Krametter-Froetscher R, Duenser ... [20] Saa LR, Perea A, García-Bocanegra I, Arenas ... [21] Shirvani E, Lotfi M, Kamalzadeh M, Noaman V, Bahriari M, ... [22] Hemmatzadeh F, Boardman W, Alinejad A, Hematzade A, Moghadam MK. Molecular ... [23] Nelson DD, Duprau JL, Wolff PL, ... [24] Ghaemmaghami S, Ahmadi M, Deniko A, ... [25] Houe H. Epidemiological features ... [26] Mayameei A, Mohammadi G, Yavari S, Afshari E, Omidi A. Evaluation ... [27] Madadgar O, Nazaktabar A, Keivanfar H, Zahraei Salehi T, Lotfollah Zadeh S. Genotyping ... [28] Mayameii A, Shapouri MRSA, Ghorbanpour M, ... [29] Vilcek S, Herring AJ, Herring JA, Nettleton PF, Lowings JP, Paton DJ. Pestiviruses isolated ... [30] Ghorbanpour M, Keyvanfar H, ... [31] Pourasgari F, Kaplon J, ... [32] Lotfi M, Bakhshesh M, Fallahi R. ... [33] Basera SS, Singh R, Vaid ,... [34] Swiatek DL, Palombo EA, Lee A, ... [35] Monini M, Cappuccini F, Battista P, Falcone E, Lavazza A, Ruggeri FM. Molecular ... [36] Hassine-Zaafrane M, Sdiri-Loulizi K, Ben Salem IB, Kaplon J, Ayouni S, Ambert-Balay K, et al. The ... [37] Sdiri-Loulizi K, Gharbi-Khélifi H, de ... [38] Eesteghamati A, Gouya M, Keshtkar ... [39] Khalili B, Cuevas LE, Reisi ... [40] Zarnani AH, Modarres S, Jadali F, Sabahi F, Moazzeni SM, Vazirian F. Role ... [41] Carbonero A, Maldonado A, Perea A, ... [42] Scharnböck B, Roch F-F, Richter V, Funke C, Firth CL, Obritzhauser W, et al. A meta-analysis of ... [43] Zhong F, Li N, Huang X, Guo Y, Chen H, Wang X, et al. Genetic ... [44] Bhudevi B, Weinstock D. ... [45] Brodersen BW. Bovine respiratory syncytial ... [46] Svensson C, Liberg P. The ... [47] Khodakaram-Tafti A, Mohammadi A, Farjani Kish GH .... [48] Canal CW, Hotzel I, de Almeida LL, ... [49] Deregt D, Carman PS, Clark RM, Burton KM, Olson WO, Gilbert SA. A comparison ... [50] Kim SG, Dubovi EJ. A novel simple one-step ... [51] Horner GW, Tham KM, Orr D, Ralston J, ... [52] Safarpoor Dehkordi F. Prevalence study of bovine ...

Copyright(C) 2021, TMU Press. This open-access article is published under the terms of the Creative Commons Attribution-NonCommercial 4.0 International License which permits Share (copy and redistribute the material in any medium or format) and Adapt (remix, transform, and build upon the material) under the Attribution-NonCommercial terms. 


\section{Introduction}

Calf diarrhea (scours) plays a major role in economic losses in cattle husbandry industry worldwide because of causing high mortality and morbidity rate ${ }^{[1-4]}$. According to the National Animal Health Monitoring System (NAHMS) for U.S. (http://nahms. aphis.usda.gov/dairy/index.htm) as well as East Asia dairy [2], the calf diarrhea is responsible for approximately more than $50 \%$ of deaths in diarrheic unweaned calves. The main causative agents of enteric infections, such as viruses (rotavirus, coronavirus, bovine viral diarrhea virus 1 and 2, and etc.), bacteria (Escherichia coli K99 (F5), in rare cases Clostridium spp. and salmonella), and protozoa (Cryptosporidium parvum) are involved in the development of calf scouring ${ }^{[5-6]}$. The epidemiology of infectious agent and the incidence of related disease are influenced by geographical region, farm management, preventive and control measures, and herd size ${ }^{[7]}$. Although the cattle husbandry industry has made great improvements, calf diarrhea has still remained as a problematic issue needing continuous intelligent prevention and control strategies [7].

BRVs, composing of 11 double-stranded RNA segments, are RNA viruses belonging to the genus Rotavirus and the family Reoviridae with seven serogroups (A-G). BRVs mostly belong to the group $A$. These viruses are detected by antigenic similarity of the intermediate capsid protein (VP6), which is responsible for infectivity ${ }^{[8-9]}$. BRVs are characterized as the main viral etiological agents of acute calf diarrhea ${ }^{[8,10-11]}$ with a very short incubation period $(12 \sim 24 \mathrm{~h})$, which cause maldigestive and malabsorptive diarrhea in unweaned calves with the age ranges from five day to less than three weeks [12-13]. Moreover, there are strong concerns about the interspecies transmission and genetic reassortment between human and domestic animal rotaviruses (such as bovine, feline, canine, and swine) ${ }^{[13]}$ The common laboratory methods used to diagnose BRVs include viral isolation, electron microscopy (EM), Capture ELISA (Enzyme linked immunosorbent assay), latex agglutination, fluorescence immunoassay, polyacrylamide gel electrophoresis (PAGE), hybridizationpoint detection method, and real time PCR [7, 14-15]. Continuous and accurate detection of BRV is essential for a better understanding of viral epidemiology and prevalence within the country to develop strategies and programs for vaccination, therapy, control, and awareness of the risk of zoonotic transmission.

Another important viral causative agent enumerated in calf diarrhea is bovine viral diarrhea virus (BVDV) which was first identified with serum neutralization (NS) test by Mirshamsy et al. in 1970 in Iran ${ }^{[16] . ~}$ BVDV is a member of the family Flaviviridae characterized by their positive-sense single stranded RNA genome [17]. Most domestic and wild animals could be infected by direct transmission and act as a reservoir. Causing potential persistent infection (PI), BVDV leads to primary damage to enterocytes and co-infection with replication in crypt enterocytes and lesion formation ${ }^{[7]}$.

The virus causes symptoms in the reproductive, digestive, and respiratory systems and causes major economic losses to herd husbandry ${ }^{[20]}$. The environmental factors and principled herd management help control and treat BVDV infection [20]. Although sero-positivity in older cattle are more than younger animals [21], the first outbreak of gastro-neuro-pathogenic BVDV infection with server clinical signs in Iran was reported in calves [22]. Pestiviruses vertical transmission plays an important role in epidemiology, pathogenesis, and persistence infection (PI) in animals which shed the infection in flocks and herds ${ }^{[23]}$. 
The sero-molecular prevalence of BVDV infection varies in different countries and even between different provinces/regions within a country ${ }^{[24-26]}$.

There is no report on BVDV detection by more reliable and sensitive methods such as RT-PCR and ELISA assays in Iran yet.

There are several reports on antigenic and molecular detection of BRV in calves in

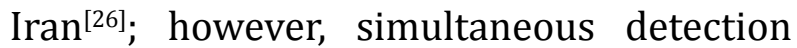
of viral infectious agents by ELISA and RTPCR methods and comparison of these techniques have not yet been reported.

The epidemiological studies in Iran have shown that the prevalence rate of bovine rotavirus in diarrheic calves varies from 26.9 to $49.4 \%$, depending on the sample collection season and province [26-28]. Therefore, it is essential to perform continuous, comprehensive, and up-to-date studies to more accurately determine the prevalence of BRV and BVDV in diarrheic calves (in both infected and PI calves) by serological and more precise methods such as RT-PCR.

Objectives: The objectives of the present study were to investigate the prevalence of rotavirus diarrhea in dairy calves by serological and molecular methods in some provinces of Iran and to compare the diagnostic efficiency of ELISA and RTPCR as well as to study the seasonal and geographical frequency of BRV and BVDV in E. coli k99-negative diarrheic fecal samples of calves.

\section{Materials and Methods}

Principles of procedure: All experiments were performed in compliance with the relevant laws and institutional guidelines using methods approved by the committee of Razi Vaccine and Serum Research Institute, IR Iran.

Sample collection: A total of 73 E. coli-negative diarrheic fecal samples were collected for this cross-sectional study from one-week to less than one-month-old calves with clinical signs of diarrhea, diagnosed by veterinarians using ELISA assay, from the industrial and semiindustrial Holstein dairy cattle herds of Alborz (Karaj), Tehran (Varamin, Shahriar, Eslamshahr, and Robatkarim), Qazvin, Hamedan, Qom, and Golestan provinces (Figure 1) and immediately stored at $-20^{\circ} \mathrm{C}$ for further study. The stool samples were collected along with the demographic data during autumn and winter from September 2018 to March 2019.

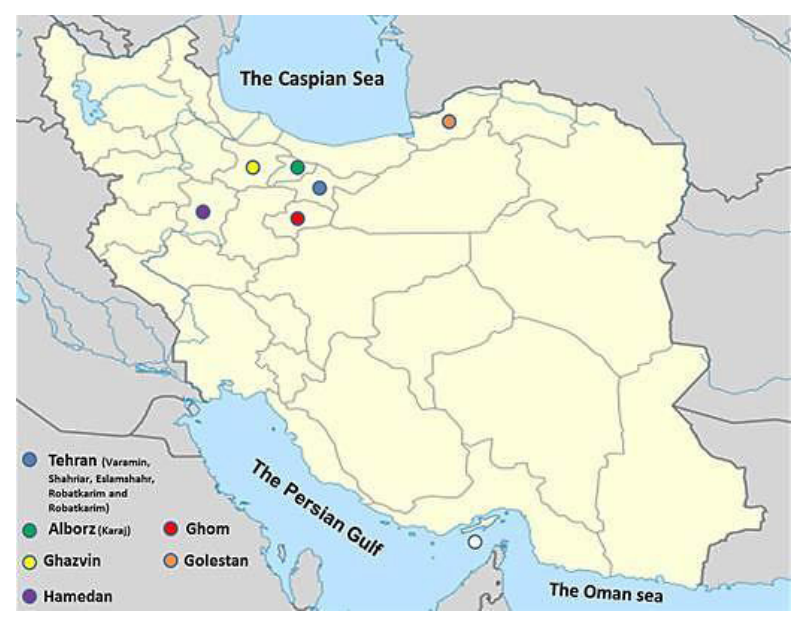

Figure 1) Infographic map of Iran and the location of provinces sampled in the present study. Six provinces (including Tehran, Alborz, Ghazvin, Hamedan, Ghom, and Golestan) were targeted, and they have important and central role in dairy production.

\section{ELISA (Enzyme-Linked Immunosorbent} Assay): A total of 85 stool samples were tested using a commercial sandwich Bio-X (BIO K 343 Monoscreen AgELISA Bovine rotavirus / sandwich, double wells) antigen detection ELISA kit from SPRL, Belgium Co., used for BRV. The IDEXX® BVDV AgELISA kit helps identify bovine viral diarrhea virus in diarrhea samples. The tests were followed according to the instructions of the manufacturer.

An ELISA reader was set at $450 \mathrm{~nm}$, and all steps were followed according to the manufacturer's instructions. The sensitivity and specificity of the ELISA technique for 
the detection of these pathogens is at least as good as the more classical techniques with very similar results. Also, the ELISA technique is rapid and reliable, especially suitable for analyzing a significant number of samples.

Moreover, ELISA (AbELISA) kit was used for serodiagnosis of $E$. coli F5 attachment factor (BIO K 295 Monoscreen AbELISA E. coli F5 (K99)) (bio-X Diagnostics ${ }^{\circledR}$, Belgium), as a blocking test for blood sera and plasma. ELISA Microplate was coated by a monoclonal antibody specific for F5 attachment factor of $E$. coli.

Sample preparation for RT-PCR: Initially, $10 \%(\mathrm{~W} / \mathrm{V})$ stool samples suspension was prepared using double-distilled water by homogenizing with mortar, then $100 \mu \mathrm{l}$ of supernatant was centrifuged at $3000 \mathrm{rpm}$ for $15 \mathrm{~min}$ at $4{ }^{\circ} \mathrm{C}$ in a refrigerated centrifuge.

RNA extraction: The supernatant of centrifuged stool samples was transferred to $2 \mathrm{~mL}$ tubes, and $1 \mathrm{~mL}$ of ice-cold RNXplus solution (CinnaGen, Iran; RNX-Plus is a Guanidine/phenol solution for total RNA isolation from homogenized sample) was added to each tube for total RNA isolation according to the manufacturer's instructions. Then the samples were vortex for $10 \mathrm{sec}$ and incubated at room temperature for $5 \mathrm{~min}$. Then $200 \mathrm{~mL}$ of chloroform was added to each tube. The tubes were shaken for $15 \mathrm{sec}$ and incubated at $4{ }^{\circ} \mathrm{C}$ for $5 \mathrm{~min}$. In continue, the samples were centrifuged at 12,000 $\mathrm{rpm}$ and $4^{\circ} \mathrm{C}$ for $15 \mathrm{~min}$. The aqueous supernatant phase was transferred to new RNase-free $1.5 \mathrm{~mL}$ tubes, and to which equal volume of Isopropanol was added with gentle inverting and then incubated on ice for $15 \mathrm{~min}$. The samples were centrifuged at $12,000 \mathrm{rpm}$ and $4^{\circ} \mathrm{C}$ for 15 min. The supernatant was discarded, and $1 \mathrm{~mL}$ of $75 \%$ ethanol was added, shortly vortexed to dislodge the pellet, and then centrifuged at $4^{\circ} \mathrm{C}$ for $8 \mathrm{~min}$ at 7,500 rpm. The supernatant was discarded, and the pellet was left to be dried at room temperature for few minutes. Finally, each sample pellet was re-suspended in a 50 $\mu \mathrm{L}$ of DEPC-treated water and placed in a $50^{\circ} \mathrm{C}$-water bath for $7 \mathrm{~min}$. The purity, yield, and integrity of the extracted total samples RNAs were determined by NanoDrop spectrophotometer (Thermo fisher scientific, Waltham, MA, USA), and the 260/280 UV absorption ratio was calculated. The extracted RNA was directly used for synthesis of cDNA or stored at $-70{ }^{\circ} \mathrm{C}$.

cDNA synthesis: Sinaclon first strand cDNA synthesis Kit was employed for cDNA synthesis of both BRV and BVDV with some modifications. At first, $1 \mu \mathrm{L}(0.20 \mu \mathrm{g})$ of random hexamer primer was added to $8 \mu \mathrm{L}$ of extracted RNA and $5 \mu \mathrm{L}$ of DEPC (Diethyl pyrocarbonate)-treated water in a nuclease free micro-tube, and the mixture was heated at $95^{\circ} \mathrm{C}$ for $5 \mathrm{~min}$ and then cooled on ice for 2 min. Then cDNA synthesis mixture was prepared as follows; $2 \mu \mathrm{L}$ of $10 \mathrm{mM}$ dNTP mix, $0.5 \mu \mathrm{L}(20 \mathrm{u})$ of RNase Inhibitor, 0.5 M-MuLV reverse transcriptase, and $2 \mu \mathrm{L}$ of 10X RT reaction buffer were added to each tube, resulting, with DEPC, in a final volume of $20 \mu \mathrm{L}$. Then the mixture was incubated at $25^{\circ} \mathrm{C}$ for $10 \mathrm{~min}, 42^{\circ} \mathrm{C}$ for $70 \mathrm{~min}$, and $90^{\circ} \mathrm{C}$ for $5 \mathrm{~min}$. The cDNA was stored at $-20^{\circ} \mathrm{C}$ until use.

Reverse Transcriptase PCR (RT-PCR) amplification: For the molecular detection of bovine rotavirus, VP6 gene was amplified using a primer set given in Table 1 as described by Iturriza Gómara et al. (2002) ${ }^{[10]}$. PCR conditions were optimized for the amplification of VP6 gene ( $348 \mathrm{bp}$ ) of bovine rotavirus and 5' UTR gene of BVDV. Optimized reaction mixture for PCR consisted of $2.0 \mu \mathrm{L}$ of cDNA, $2.0 \mu \mathrm{L}$ of $2 \mathrm{mM}$ PCR buffer, $2.5 \mu \mathrm{L}$ of $25 \mathrm{mM}$ dNTPs, $2.5 \mu \mathrm{L}$ of $\mathrm{MgCl}_{2}, 3.0 \mu \mathrm{L}$ of 10 
Table 1) Primers and thermal timing program used to detect BRV and BVDV.

\begin{tabular}{|c|c|c|c|c|c|c|}
\hline Primer Name & \multicolumn{2}{|c|}{ Primer Sequence $\left(5^{\prime}-3^{\prime}\right)$} & Sense & \multicolumn{2}{|c|}{ Primer Length } & $\begin{array}{l}\text { Expected } \\
\text { Amplicon }\end{array}$ \\
\hline VP6-F3 & \multicolumn{2}{|c|}{$\begin{array}{l}\text { 5'-GACGGVGCRACTACATGGT-3' }^{\prime} \\
\text { (nt: 737-755) }\end{array}$} & + & \multicolumn{2}{|c|}{19} & \\
\hline VP6-R3 & \multicolumn{2}{|c|}{$\begin{array}{l}\text { 5'-GTCCAATTCATNCCTGGTG-3' } \\
\text { (nt: 1116-1098) }\end{array}$} & - & \multicolumn{2}{|c|}{19} & 348 \\
\hline $\begin{array}{l}\text { Pan-pestivirus } \\
\text { primer, p324 }\end{array}$ & \multicolumn{2}{|c|}{ 5'-ATGCCCWTAGTAGGACTAGCA-3' } & + & \multicolumn{2}{|c|}{21} & 288 \\
\hline p326 & \multicolumn{2}{|c|}{ 5'-TCAACTCCATGTGCCATGTAC-3' } & - & \multicolumn{2}{|c|}{21} & \\
\hline Target & $\begin{array}{c}\text { Initial } \\
\text { Denaturation }\end{array}$ & Denaturation & Annealing & Extension & $\begin{array}{c}\text { Final } \\
\text { Extension }\end{array}$ & Cycle \\
\hline BRV & $94^{\circ} \mathrm{C}, 5 \mathrm{~min}$ & $94^{\circ} \mathrm{C}, 40 \mathrm{sec}$ & $55^{\circ} \mathrm{C}, 30 \mathrm{sec}$ & $72^{\circ} \mathrm{C}, 30 \mathrm{sec}$ & $72^{\circ} \mathrm{C}, 5 \mathrm{~min}$ & 40 \\
\hline BVDV & $95^{\circ} \mathrm{C}, 3 \mathrm{~min}$ & $95^{\circ} \mathrm{C}, 40 \mathrm{sec}$ & $56^{\circ} \mathrm{C}, 30 \mathrm{sec}$ & $72^{\circ} \mathrm{C}, 20 \mathrm{sec}$ & $72^{\circ} \mathrm{C}, 5 \mathrm{~min}$ & 40 \\
\hline
\end{tabular}

pmol VP6-1 F, $6.0 \mu \mathrm{L}$ of 10 pmol VP6-2 R, 0.5 $\mu \mathrm{L}$ of Taq DNA Polymerase, and $6.5 \mu \mathrm{L}$ of $\mathrm{dH}_{2} \mathrm{O}$. Timing program and conditions for the amplification of the VP6 gene of bovine rotavirus are presented in Table 1. Steps 2-4 were repeated 40 times to get the required products of VP6 and 5' UTRgenes amplification. To analyze the PCR amplification products, agarose gel electrophoresis was performed. Thus, $1.2 \%$ gel was prepared, and $1 \mu \mathrm{L}$ of 100 bp DNA ladder along with the PCR product was run at 90 volts for $55 \mathrm{~min}$. Also, details of PCR for BVDV are arranged in Table 1. Panpestivirus primers (p324 F and p326) were used for BVDV detection [29].

Gel electrophoresis and visualization: PCR products were visualized by agarose gel electrophoresis (1.2\%) in TBE (Tris Base, boric acid, EDTA, pH 8, 0.5 M) with Safe-stain staining following 55 min electrophoresis at $90 \mathrm{~V}$. Also, 100 bp Plus DNA Ladder (Fermentas, Germany) was used as marker on each gel run. Samples that showed bands with corresponding weights at Table 1 were considered as positive.

Sequencing, registering, and BLASTing of sequences: For verification of BRV amplified fragments, positive samples of PCR products were prepared and directed for sequencing using standard Sanger sequencing technology to Microsynth Company (Microsynth, Switzerland). Finch TV (Geospiza Inc, Seattle, USA) and BioEdit 6.6.9 software were used to view, analyze, and edit the sequences. Finally, a sequence was submitted directly by authors to GenBank database by BankIt tool. After registering the sequences, sequenced data were directed to Blast and compared against the GenBank library using the BLAST tool (http://blast.ncbi.nlm.nih.gov/Blast.cgi). Statistical analysis: For statistical data analysis, frequency distribution was applied. Also, the association between qualitative variables was examined using Chi-square, and a $p$ value of $<.05$ was considered as statistically significant. SPSS software Ver. 22 was used for data analysis.

\section{Findings}

Molecular and antigen detection: In this study, among the 73 diarrheic fecal samples collected during the entire two seasons, BRV antigen was detected in 28 (38.3 \%) samples using antigen capture sandwich ELISA. Also, 31 (42.4 \%) samples were found to be positive for rotavirus using RT-PCR test. The 
Table 2) Measurement of the Kappa coefficient. As shown, the results of the two tests do not agree.

\begin{tabular}{llccc}
\hline \multicolumn{4}{l}{ Symmetric Measures } & \\
\hline & Value & Asymp. Std. Error ${ }^{\mathrm{a}}$ & Approx. T & Approx. Sig. \\
Measure of Agreement (Kappa) & 0.404 & 0.108 & 3.462 & 0.001 \\
No. of Valid Cases & 73 & & & \\
\hline
\end{tabular}

a. Not assuming the null hypothesis.

b. Using the asymptotic standard error assuming the null hypothesis.

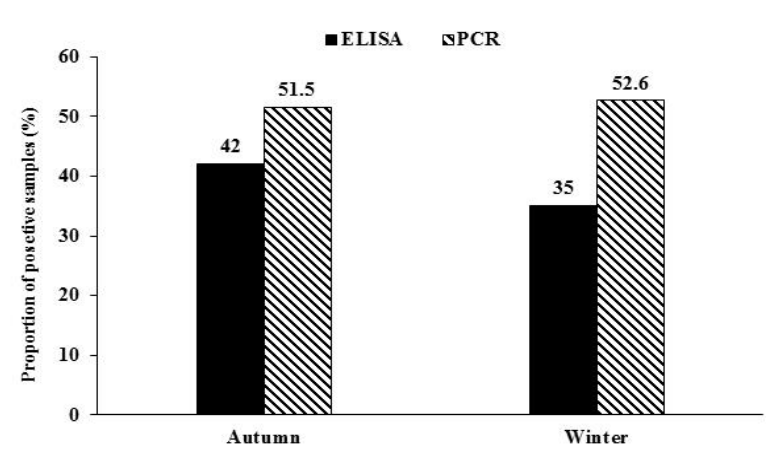

Figure 2) Comparison of rotavirus prevalence in diarrheic calves in Iranian industrial and semi-industrial dairy herds, measured during autumn and winter via different diagnostic methods.

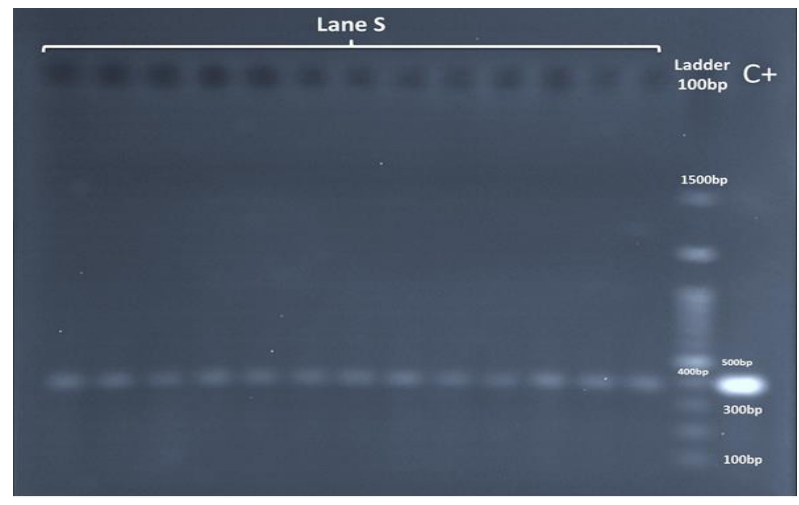

Figure 3) RT-PCR amplification of conserved part of VP6 gene of bovine group A rotavirus with $\sim 348$ bp amplicon; from right to left: Lane 1: positive control, Lane 2: $100 \mathrm{bp}$ plus DNA ladder, and Lane $S$ : positive samples

Kappa coefficient (ELISA and RT-PCR) was 0.404 , indicating that the results of two tests were inconsistent (Table 2). Only one sample from Hamedan province was BVDV positive $(O D=0.506)$ using ELISA, and this sample was negative for rotavirus using ELISA and

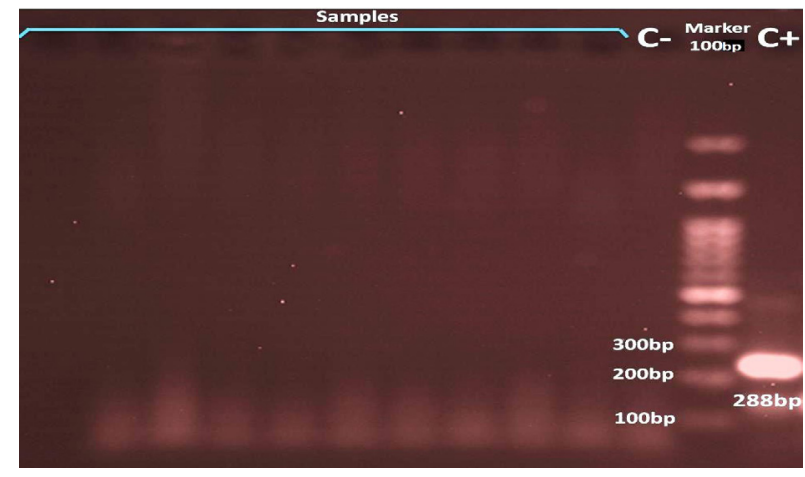

Figure 4) RT-PCR amplification of conserved part of 5' UTR gene of BVDV with 288 bp amplicon; from right to left: Lane 1: positive control (C+), Lane 2: 100 bp plus DNA ladder, Lane 3: negative control (C-), other lanes: samples

PCR. But in RT-PCR by positive control, this sample and all other samples were negative for BVDV.

In addition, the distribution of the positive samples by city showed that $80,52.6$, and $50 \%$ of samples collected from Eslamshahr, Qazvin, and Hamedan were BRV positive, respectively, indicating the high prevalence rate of $\mathrm{BRV}$ in these cities/provinces. In most cities/provinces, the results of ELISA and PCR tests for BRV detection were almost the same, but in Islamshahr and Shahriar, the percentage of ELISA-positive samples was higher than that of PCRpositive samples, and in Shahriyar, PCRpositive cases were screened as negative by ELISA.

In addition, BRVA positive samples by ELISA and RT-PCR tests were 42\% (14 from 33) 
and $51.5 \%$ (17 from 33) in autumn, and $35 \%$ (14 from 40 ) and 52.6\% (10 from 19) in winter, respectively, suggesting that the prevalence rate was significantly higher in autumn using ELISA, while it was higher in winter using RT-PCR (Figure 2). In case of BVDV, only one ELISA-positive sample was reported in autumn. Furthermore, all the samples by ELISA assay were negative for $E$. coli F5 antigen (K99).

Electrophoresis, sequencing, and BLASTing: After RNA extraction and cDNA synthesis, the PCR amplification was done for VP6 and 5' UTR genes. After visualization of $348 \mathrm{bp}$ bonds in gel electrophoresis, amplified fragments were sent to Macrogen Co., South Korea for direct sequencing. Partial VP6 genes sequencing data quality was confirmed by Finch TV software (Geospiza Inc, Seattle, USA). Nucleotide sequences of partial VP6 genes of Iranian BRV were used as entry data to search for probable most similar sequences in NCBI BLAST database.

Electrophoresis results are demonstrated in Figure 3 (for bovine rotavirus) and Figure 4 (for BVDV).

\section{Discussion}

Using both antigen detection and molecular methods, the present study results showed that rotavirus had a high prevalence rate among diarrheic calves (approximately $40 \%, 38.3 \%$ by capture sandwich ELISA and $42.4 \%$ by RT-PCR). This result is consistent with the results of previous studies in Iran, reporting high prevalence rates of BRV infection in dairy farms of different province of Iran (such as Tehran, Mashhad, Fars, Markazi, Chaharmahal and Bakhtiari, Khorasan, West Azerbaijan, etc.) [26, 30]. Madadgar et al. (2015) ${ }^{[27]}$ using only ELISA technique reported that out of 109 samples collected from some provinces of Iran, 28.2\% were positive for bovine rotavirus group A (BRVA). Also, Pourasgari et al. (2016) ${ }^{[31]}$ using RT-PCR method showed that $49.4 \%$ (125 out of 253 ) of the samples were positive for bovine RV. Another study examining the association between rotavirus and diarrhea in newborn calves in some industrial dairy herds using ELISA revealed that RVA was positive in $29.5 \%$ of cases ${ }^{[26]}$.

In another study, by isolation of BRV from diarrheic fecal samples of calves in Tehran and Alborz provinces, out of 41 samples, the cytopathic effect (CPE) were observed in 13 samples (31.7\%) (4 samples from Shahriar, 5 samples from Robatkarim, 3 samples from Eslamshahr, and 1 sample from Pakdasht) ${ }^{[32]} \mathrm{A}$ review of literature in different countries of the world revealed that the prevalence rate of rotavirus in screened diarrheal calves varied from 10 to $94 \%$ (with $5-20 \%$ mortality rate) and in Iran, it varied from 26.9 to $34 \%$ in neonatal calves, depending on the methods of detection, breed, season, and province under study [12, 26, 33]. It has been reported that the average incidence and prevalence of the infection is between $30-40 \%$ [34]. Our results in Iran are consistent with the reported average rate and similar to these findings.

Molecular based methods such as RTPCR are successfully used as a reliable epidemiological test for BRV detection, although there are complexities in the detection of novel or uncommon rotavirus genotypes and mixed infections [10, 35]. Moreover, RT-PCR is a more promising technique than ELISA and some other techniques as well as is considered as a confirmatory technique for detecting group A rotaviruses because only a very small quantity of RNA is necessary ${ }^{[33]}$. To confirm this, in this study, the positive cases detected by RT-PCR were more than those detected by ELISA test. 
Previous studies have reported higher rates of rotavirus genus infection mainly between November and April in the world [36-37], including Iran [38-40]

This study showed similar results and a high prevalence rate of BRV infection in winter season.

Serological studies on the prevalence rate of BVDV in adult cattle and buffalo (over 1 year) have generally reported a prevalence rate between $20-60 \%$, indicating a high rate of infection in Iranian herds. The serological prevalence of this agent in Europe and America is much lower than in Asian, African, and Latin American countries [41-43].

Accurate detection and elimination of persistently infected (PI) calves, those calves born from cows exposed to BVDV virus during 30-150 days of gestation, by seromolecular methods is of great important in controlling the transmission of the virus and overall herd health management ${ }^{[44-46]}$. Therefore, the double-edged purpose of the current study was to comparatively detect BVDV and BRV by capture ELISA and RTPCR assays simultaneously in diarrheic fecal samples of calves with respect to demographic data. This study was the first detection of BVDV in calves' diarrhea samples by both ELISA and PCR methods. Only one sample from Hamedan province was BVDV-positive in ELISA assay, but in RT-PCR, all the samples were negative, and PCR did not confirm the ELISA-positive sample.

Different methods are used to detect naturally infected and PI calves ${ }^{[47]}$, RT-PCR which is used both as a primary method and as a confirmatory method, is a rapid, sensitive, and more adaptable technique for detecting pestiviruses nucleic acids in a variety of clinical samples ${ }^{[48-50]}$. Also, antigen capture ELISA and cell culture immunoperoxidase tests for detecting
BVDV are more time-consuming and laborintensive than RT-PCR method [51-52]. PI calves shedding viruses by secretion and excretion into the herd population for a long time, are known as the major source of BVDV infections in herds ${ }^{[7,23]}$. Detection of these calves in herds are of great important in animal health management.

\section{Conclusion}

The use of molecular (PCR-based techniques) and antigen detection (such as ELISA) methods, as epidemiological data gathering tools, to evaluate the prevalence and incidence of BRV and BVDV, as common causative agents of calf diarrhea, facilitates the design of future strategies and programs to control, manage, and develop effective mass vaccination for the disease. Besides, it helps better understand the roles of different microorganisms and seasons in the occurrence of diarrhea syndrome.

Acknowledgements:This work was funded in part by Razi Vaccine \& Serum Research Institute, Karaj, Iran (Grant No. 2-18-18091-960991).

Ethical Permisions: The project and data collection procedure were approved by the Ethics Committee of the Razi Vaccine and Serum Research Institute, Karaj, Iran.

Conflicts of Interests: The authors declared no competing interest.

Authors' Contributions: Conceptualization: MMR; Data curation and formal analysis: SE, SRM and GRK; Investigation: SE; Methodology and project administration: MLK, ARY, SMA, SRM and SY; Supervision: MMR; Validation: MMR, SE, ML, ARY, SMA, SRM, SY and GK; Writing of original draft: MMR; Writing, reviewing, and editing: MMR. Fundings: This study was financially supported by the Razi Vaccine and Serum Research Institute, Karaj, Iran.

Consent to participate:Not applicable. 


\section{References}

1. Achá SJ, Kühn I, Jonsson P, Katouli M, Möllby R. Studies on calf diarrhoea in Mozambique: Prevalence of bacterial pathogens. Acta Vet Scand. $2004 ; 45(1): 27-36$.

2. Hur T-Y, Jung Y-H, Choe C-Y, Cho YI, Kang SJ, Lee HJ, et al. The dairy calf mortality: The causes of calf death during ten years at a large dairy farm in Korea. Korean J Vet Res. 2013;53(2):103-8.

3. Østerås 0 , Gjestvang MS, Vatn S, Sølverød L. Perinatal death in production animals in the Nordic countries - incidence and costs. Acta Vet Scand. 2007;49(S1):S14.

4. Reynolds DJ, Morgan JH, Chanter N, Jones PW, Bridger JC, Debney TG, et al. Microbiology of calf diarrhoea in southern Britain. Vet Rec. 1986;119(2):34-9.

5. Bartels CJM, Holzhauer M, Jorritsma R, Swart WAJM, Lam TJGM. Prevalence, prediction, and risk factors of enteropathogens in normal and nonnormal faeces of young Dutch dairy calves. Prev Vet Med. 2010;93(2-3):629.

6. Izzo MM, Kirkland PD, Mohler VL, Perkins NR, Gunn AA, House JK. Prevalence of major enteric pathogens in Australian dairy calves with diarrhoea. Aust Vet J. 2011;89(5):167-73.

7. Cho Y, Yoon K-J. An overview of calf diarrhea - infectious etiology, diagnosis, and intervention. J Vet Sci. $2014 ; 15(1): 1-17$.

8. Chen S-C, Tan L-B, Huang L-M, Chen K-T. Rotavirus infection and the current status of rotavirus vaccines. J Formos Med Assoc. 2012;111(4):183-93.

9. Greenberg HB, Estes MK. Rotaviruses: from pathogenesis to vaccination. Gastroenterology. 2009; 136 (6): 193951.

10. Iturriza Gómara M, Wong C, Blome
S, Desselberger U, Gray J. Rotavirus subgroup characterisation by restriction endonuclease digestion of a cDNA fragment of the VP6 gene. J Virol Methods. 2002;105(1):99-103.

11. Maclachlan NJ, Dubovi EJ. Retroviridae: Fenner's veterinary virology. 4th ed. Elsevier, 2011,243-74.

12. Dhama K, Chauhan RS, Mahendran M, Malik SVS. Rotavirus diarrhea in bovines and other domestic animals. Vet Res Commun. 2009;33(1):1-23.

13. Martella V, Bányai K, Matthijnssens J, Buonavoglia C, Ciarlet M. Zoonotic aspects of rotaviruses. Vet Microbiol. 2010;140(3-4):246-55.

14. Buesa J, Colomina J, Raga J, Villanueva A, Prat J. Evaluation of reverse transcription and polymerase chain reaction (RT/PCR) for the detection of rotaviruses: Applications of the assay. Res Virol. 1996;147(6):353-61.

15. Fan Q, Xie Z, Xie Z, Deng X, Xie L, Huang L, et al. Development of a GeXP-multiplex PCR assay for the simultaneous detection and differentiation of six cattle viruses. PLoS One. 2017;12(2):e0171287.

16. Garoussi MT, Mehrzad J, Nejati A. Investigation of persistent infection of bovine viral diarrhea virus (BVDV) in Holstein dairy cows. Trop Anim Health Prod. 2019;51(4):853-8.

17. Liu L, Xia $H$, Wahlberg N, Belák $S$, Baule C. Phylogeny, classification, and evolutionary insights into pestiviruses. Virology. 2009;385(2):351-7.

18. Grøndahl C, Uttenthal A, Houe $H$, Rasmussen TB, Hoyer MJ, Larsen L. Characterisation of a pestivirus isolated from persistently infected mousedeer (Tragulus javanicus). Arch Virol. 2003;148(8):1455-63.

19. Krametter-Froetscher R, Duenser $M$, Preyler B, Theiner A, Benetka V, Moestl K. Pestivirus infection in sheep and goats 
in West Austria. Vet J. 2010;186(3):3426.

20. Saa LR, Perea A, García-Bocanegra I, Arenas AJ, Jara DV, Ramos R, et al. Seroprevalence and risk factors associated with bovine viral diarrhea virus (BVDV) infection in non-vaccinated dairy and dual purpose cattle herds in Ecuador. Trop Anim Health Prod. 2012;44(3):645-9.

21. Shirvani E, Lotfi M, Kamalzadeh M, Noaman V, Bahriari M, Morovati $H$, et al. Seroepidemiological study of bovine respiratory viruses (BRSV, BoHV-1, PI$3 \mathrm{~V}, \mathrm{BVDV}$, and BAV-3) in dairy cattle in central region of Iran (Esfahan province). Trop Anim Health Prod. 2012;44(1):191-5.

22. Hemmatzadeh F, Boardman W, Alinejad A, Hematzade A, Moghadam MK. Molecular and serological survey of selected viruses in free-ranging wild ruminants in Iran. PLoS One. 2016;11(12):e 0168756.

23. Nelson DD, Duprau JL, Wolff PL, Evermann JF. Persistent bovine viral diarrhea virus infection in domestic and wild small ruminants and camelids including the mountain goat (Oreamnos americanus). Front Microbiol. 2016;6:1415.

24. Ghaemmaghami S, Ahmadi M, Deniko A, Mokhberosafa L, Bakhshesh M. Serological study of BVDV and BHV1 infections in industrial dairy herds of Arak, Iran. Iran J Vet Sci Technol. 2013;5(2):53-61.

25. Houe H. Epidemiological features and economical importance of bovine virus diarrhoea virus (BVDV) infections. Vet Microbiol. 1999;64(2-3):89-107.

26. Mayameei A, Mohammadi G, Yavari S, Afshari E, Omidi A. Evaluation of relationship between rotavirus and coronavirus infections with calf diarrhea by capture ELISA. Comp Clin Path. 2010;19(6):553-7.

27. Madadgar 0, Nazaktabar A, Keivanfar H, Zahraei Salehi T, Lotfollah Zadeh S. Genotyping and determining the distribution of prevalent $G$ and $P$ types of group A bovine rotaviruses between 2010 and 2012 in Iran. Vet Microbiol. 2015;179(3-4):190-6.

28. Mayameii A, Shapouri MRSA, Ghorbanpour M, Hajikolaei MRH, Keyvanfar H. Molecular G typing of bovine rotaviruses in Iran. Pakistan J Biol Sci. 2007;10(19):3466-9.

29. Vilcek S, Herring AJ, Herring JA, Nettleton PF, Lowings JP, Paton DJ. Pestiviruses isolated from pigs, cattle and sheep can be allocated into at least three genogroups using polymerase chain reaction and restriction endonuclease analysis. Arch Virol. 1994;136(34):309-23.

30. Ghorbanpour M, Keyvanfar H, Shapouri SA. The dsRNA electrophoretype of some isolated Iranian calf rotaviruses. Arch Razi Inst. 2004;58(1):85-9.

31. Pourasgari F, Kaplon J, Karimi-Naghlani S, Fremy C, Otarod V, Ambert-Balay $\mathrm{K}$, et al. The molecular epidemiology of bovine rotaviruses circulating in Iran: A two-year study. Arch Virol. 2016;161(12):3483-94.

32. Lotfi M, Bakhshesh M, Fallahi R. Isolation and G-typing of rotaviruses from diarrheal calves in Tehran and Alborz provinces, Iran. Arch Razi Inst. 2015;70(4):237-43.

33. Basera SS, Singh R, Vaid N, Sharma K, Chakravarti S, Malik YP. Detection of rotavirus infection in bovine calves by RNA-PAGE and RT-PCR. Indian J Virol. 2010;21(2):144-7.

34. Swiatek DL, Palombo EA, Lee A, Coventry MJ, Britz ML, Kirkwood CD. Detection and analysis of bovine rotavirus 
strains circulating in Australian calves during 2004 and 2005. Vet Microbiol. 2010;140(1-2):56-62.

35. Monini M, Cappuccini F, Battista P, Falcone E, Lavazza A, Ruggeri FM. Molecular characterization of bovine rotavirus strains circulating in northern Italy, 2003-2005. Vet Microbiol. $2008 ; 129(3-4): 384-9$.

36. Hassine-Zaafrane M, Sdiri-Loulizi K, Ben Salem IB, Kaplon J, Ayouni S, Ambert-Balay $\mathrm{K}$, et al. The molecular epidemiology of circulating rotaviruses: three-year surveillance in the region of Monastir, Tunisia. BMC Infect Dis. 2011;11(1):266.

37. Sdiri-Loulizi $K$, Gharbi-Khélifi $H$, de Rougemont A, Chouchane S, Sakly N, Ambert-Balay $\mathrm{K}$, et al. Acute infantile gastroenteritis associated with human enteric viruses in Tunisia. J Clin Microbiol. 2008;46(4):1349-55.

38. Eesteghamati A, Gouya M, Keshtkar A, Najafi L, Zali MR, Sanaei M, et al. Sentinel hospital-based surveillance of rotavirus diarrhea in iran. J Infect Dis. 2009;200 (Suppl-1):S244-7.

39. Khalili B, Cuevas LE, Reisi N, Dove W, Cunliffe NA, Hart CA, et al. Epidemiology of rotavirus diarrhoea in Iranian children. J Med Virol. 2004;73(2):30912.

40. Zarnani AH, Modarres S, Jadali F, Sabahi F, Moazzeni SM, Vazirian F. Role of rotaviruses in children with acute diarrhea in Tehran, Iran. J Clin Virol. 2004;29(3):189-93.

41. Carbonero A, Maldonado A, Perea A, García-Bocanegra I, Borge C, Torralbo $\mathrm{A}$, et al. Factores de riesgo del síndrome respiratorio bovino en terneros lactantes de Argentina. Arch Zootec. 2011;60(229):41-51.

42. Scharnböck B, Roch F-F, Richter V, Funke C, Firth CL, Obritzhauser W, et al. A meta- analysis of bovine viral diarrhoea virus (BVDV) prevalences in the global cattle population. Sci Rep. 2018;8(1):1-5.

43. Zhong F, Li N, Huang X, Guo Y, Chen $H$, Wang $X$, et al. Genetic typing and epidemiologic observation of bovine viral diarrhea virus in Western China. Virus Genes. 2011;42(2):204-7.

44. Bhudevi B, Weinstock D. Detection of bovine viral diarrhea virus in formalin fixed paraffin embedded tissue sections by real time RT-PCR (Taqman). J Virol Methods. 2003;109(1):25-30.

45. Brodersen BW. Bovine respiratory syncytial virus. Vet Clin North Am Food Anim Pract. 2010;26(2):323-33.

46. Svensson C, Liberg P. The effect of group size on health and growth rate of Swedish dairy calves housed in pens with automatic milk-feeders. Prev Vet Med. 2006;73(1):43-53.

47. Khodakaram-Tafti A, Mohammadi A, Farjani Kish GH. Molecular characterization and phylogenetic analysis of bovine viral diarrhea virus in dairy herds of Fars province, Iran. Iran J Vet Res. 2016; 17(2): 89-97.

48. Canal CW, Hotzel I, de Almeida LL, Roehe PM, Masuda A. Differentiation of classical swine fever virus from ruminant pestiviruses by reverse transcription and polymerase chain reaction (RT-PCR). Vet Microbiol. 1996;48(3-4):373-9.

49. Deregt D, Carman PS, Clark RM, Burton KM, Olson WO, Gilbert SA. A comparison of polymerase chain reaction with and without RNA extraction and virus isolation for detection of bovine viral diarrhea virus in young calves. J Vet Diagn Invest. 2002;14(5):433-7.

50. Kim SG, Dubovi EJ. A novel simple onestep single-tube RT-duplex PCR method with an internal control for detection of bovine viral diarrhoea virus in bulk 
milk, blood, and follicular fluid samples. Biologicals. 2003;31(2):103-6.

51. Horner GW, Tham KM, Orr D, Ralston J, Rowe S, Houghton T. Comparison of an antigen capture enzyme-linked assay with reverse transcription--polymerase chain reaction and cell culture immunoperoxidase tests for the diagnosis of ruminant pestivirus infections. Vet Microbiol. 1995; 43 (1): 75-84.

52. Safarpoor Dehkordi F. Prevalence study of bovine viral diarrhea virus by evaluation of antigen capture ELISA and RT-PCR assay in bovine, ovine, caprine, buffalo, and camel aborted fetuses in Iran. AMB Express. 2011;1(1):1-6. 